\title{
Gatekeepers of financial power: from London to Lagos
}

\author{
Elizabeth Cobbett ${ }^{\mathrm{a}, \mathrm{b}}$
}

aDepartment of Political, Social and International Studies, University of East Anglia, Norwich Research Park,

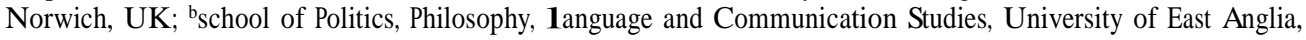
Norwich, UK

\begin{abstract}
The main premise of this paper is that, until recently, African elites did not regulate or control financial flows moving across the continent. They were not financial gatekeepers. In Africa Since 1940, Cooper identified African elites as gatekeepers regulating access to resources and opportunities passing through strategic sites. This paper makes a case for revision of existing notions of the gatekeeper state in an ongoing effort to (re)negotiate the continent's colonial past through two new arguments. The first is that financial power was never located at a 'peripheral' African gate, but resolutely held onto within leading financial centres, circumventing any opportunity for African elites to control financial flows. Failure to distinguish between types of flows distorts analysis of African political economic power under colonialism. It is only in the post-2000 period, that we see powerful African states driving the integration of African markets into the global financial system. The second argument is that these African goals to control financial flows correspond more to 'gateway' strategies than to gatekeeper. Drawing on the case of Lagos, I demonstrate how this 'gateway' concept better captures transscalar processes of new financial clustering in Africa's emerging markets than a concept associated with 'gates' under Empire.
\end{abstract}

\section{Introduction}

Colonial leaders and African rulers sat 'astride the interface between a [colonised] territory and the rest of the world, collecting and distributing resources that derived from the gate'. ${ }^{1}$ This paper makes a case for revision of Cooper's gatekeeper state in an ongoing effort to (re) negotiate the continent's colonial past through two new arguments. The first point is that financial power was never located at a 'peripheral' African gate, but resolutely held onto within leading financial centres, circumventing any opportunity for African elites to control financial flows. Failure to distinguish between types of flows distorts analysis of African polit- ical economic power under colonialism. I, therefore, make the novel argument that reviewing the 'gatekeeper' concept within the broader spectrum of finance radically alters our theori- sation of this concept. The second claim of this papers builds on present-day strategies by African public authorities to bring control of financial flows back to the continent. The 
argument being made is that contemporary African financial control of financial flows cor- responds more to 'gateway' strategies than to gatekeeper. In this context, the concept of gateway is increasingly present in policy debates and discussions to highlight a location's key role and geographical advantages in international distribution networks. Drawing on the case of Lagos, I demonstrate how this 'gateway' concept better captures trans-scalar processes of new financial clustering in Africa'semerging markets than aconceptassociated with 'gates' under Empire.

Accordingly, the first section situates London as financial gatekeeper under Empire, but- tressed by the City-Bank of England-Treasury nexus. ${ }^{2}$ African countries were tied to colonial management of their monies through a variety of policies which redirected wealth to the metropole. In the next section, I demonstrate how financial gatekeeping continued to be managed by colonial powers at the time of independence, and were further compounded by control of the Bretton Woods international financial institutions (IFIs). The third section depicts a different global context as a record levels of growth are registered on the continent in a context of rising Asia. Only more recently are we beginning to see forms of financial gatekeeping emerging across the continent, as African public authorities reach out to embed financial networks within their domestic jurisdictions. Here I suggest using the 'gateway' model, instead of that of gatekeeper, to highlight Lagos' role as West African's rising seat of financial control. This is followed by a conclusion.

\section{Financial gates under Empire}

Cooper argues that the post-colonial African state'scrises arose within the legacy of the continent's political and economic longue durée relationship with its colonising powers. Following European conquest and partition, African colonial economies created open links to export raw material to European states in exchange for manufactured and beneficiated products. ${ }^{3}$ However, between 1850 and 1945, the financial sector had a greater impact than industry on Britain's presence overseas. ${ }^{4}$ Understanding British imperialism is predicated on grasping 'the interaction between economic development and political authority in the metropole'. ${ }^{5}$ This reflects Strange's ${ }^{6}$ argument that trade is a'secondary structure'to finance. And tounderstand finance's structural power is to provideananswer to her ${ }^{7}$ question, cui bono? (who benefits?), who makes the rules and how does power influence outcomes and interests? In response to this question, this section argues that a defining feature of the colonial capitalist world system was British financial power that was never located at a 'peripheral' African gate, but resolutely held onto within London. This circumvented any opportunity for African elites to control financial flows. After 1850, British imperialism was buttressed by the financial and commercial magnates of the City, its network of Gentlemanly Capitalism, ${ }^{8}$ along with the growth of services in the south-east of England. ${ }^{9}$ This world order featured a high level of international capital mobility moving through London and freedom from controls of international financial transactions. ${ }^{10}$

For an African country to become a 'gatekeeper of financial flows' required the where- withal to manage its own currency, namely having a central bank with the monopoly of issuing money and the authority to manage the country's reserves. However, none of Britain's colonies, no matter their degree of self-government, had their own central bank. ${ }^{11}$ Colonial currency regimes promoted the metropole's interests at the expense of the colonies' devel- opment ${ }^{12}$ by maintaining the gates of finance in London. As seen in South Africa, British 
colonialism was transformed into aggressive imperialism through the creation of a new power constellation conducive to the exploitation of gold and its transfer to London. ${ }^{13}$ During the midnineteenth century, British interest in the Cape Colony and Natal was in decline as prospects for the Suez Canal (opened in 1869) made further investments into African 'out- posts' of the Empire undesirable. ${ }^{14}$ The discovery of coal in 1840s, diamonds in 1867, and gold in 1885-1886, however, triggered a mineral revolution that saw a complete turnabout in Britain's policy towards South African colonies. ${ }^{15}$ The discovery of gold coincided with the world transition, in 1870, to the British monetary system based on the gold standard. In short, the discovery of gold brought the predominantly agricultural colonies into the core of world economic relations, intimately linking them totheglobalfinancial systemoperating throughLondon. ${ }^{16}$ TheBoerWar 1899-1902 establishedBritish supremacy throughout South Arica ${ }^{17}$ as Britain's pressing goal was to ensure that the mines in the Transvaal remained independent from Afrikaner nationalist interests.

In 1917, Jan Smuts, prime minister of the Union of South Africa, came under criticism from Nationalists for allowing imperial Britain'sinterests to override South Africa'sindepend- ence. ${ }^{18}$ At the same time, the South African Chamber of Mines pushed for control over the gold refinery process instead of shipping all its unprocessed metal to London where it fell under the control of the Bank of England. Of importance to the Chamber was the interest shown locally refined gold by the USA, which saw an advantage in breaking the British monopoly and dealing directly with South African gold suppliers. ${ }^{19}$ In 1919, political oppo- sition in South Africa to the country's subordination to Britain's imperial interests finally created enough leverage to establish two key national institutions: a gold refinery and a national mint. ${ }^{20}$ Further attempts by South Africa to relax remaining ties with Britain's sterling following the latter's departure from the gold standard in September 1931 were unsuccessful and the country was forced to devalue in $1933 .{ }^{21}$ This laid the groundwork for a coalition that would later become the United South African Nationalist Party, which came into power in 1948.

South Africa is a well-known, but not exceptional case. Britain to forcibly replaced inter- national currencies across its colonies with British Indian rupees, British dollars, and British sterling silver tokens backed by gold and sterling reserves in London. ${ }^{22}$ This was buttressed by currency boards ${ }^{23}$ set up in West and East Africa by the British Treasury and the Bank of England, along with the Commonwealth Office. ${ }^{24}$ As the monetary authority for the colonies, these boards issued notes and coins in London that were convertible into a foreign currency or commodity such as gold. A currency board's reserves were required to be equal to 100 per cent or more of the notes and coins in circulation in the colonial country. The reserves, effectively assets, were held within the metropolitan capital, securing important seigniorage benefits, that is to say profits made from the difference between the interest earned on reserve assets and the expense of maintaining the notes and coins in circulation within each of the colonial countries. The size, or degree, of seigniorage profits depends directly on issuing country's monopoly of currencies within the system. ${ }^{25}$ Britain had complete monop- oly of production and circulation of currencies within its colonies, with considerable net gains from seigniorage. The West African Currency Board (WACB) was created in 1912 fol- lowing on Britain's initial experience of establishing a board in the British Indian Ocean colony of Mauritius in 1849. The WACB controlled the supply of silver tokens to Nigeria, the Gold Coast (Ghana), Sierra Leone, and Gambia, and became the working model for later currency boards, notably in East Africa. African financialinstitutions, such as TheBankofWest Africa, 
acted as the primary financial intermediaries between London and the Currency Officers. These financial institutions were not, however, gatekeepers àla Cooperbutratherfunction- aries of monetary control directing financial flows back to London.

There were no African central banks and the elites did not have the political economic power to issue money or to buy and hold domestic debt. When a central bank buys domestic assets, such as government debt, it controls the country's monetary base by paying for the debt and increasing the supply of money. A currency board does not have this power and is dependent on supply coming from control of colonial powers as market forces and the balance of payments determine the money supply. The currency board system, thus, implies prohibition of financing government deficits and consequential control on macroeconomic management. Governments cannot adjust domestic interest or exchange rates with the goal of stimulating the economy. So instead of, say, Ghana being able to raise a bond for national debt through an independent central bank - thus supporting national budget management-Britain held a deficit for Ghana in its balance of payments. This is what Cohen refers to as the 'current' portion of seigniorage benefits. It is, he explains, the ability for the issuing country, in this case Britain, to live 'beyond its means ${ }^{26}$ as it runs a continual current account deficit. This deficit in Britain grew as African colonies drew on money issued in London to act as currencies within their countries. The second portion, the'capital' benefits of seigniorage, arises from revenue from additional investments abroad made possible by the cumulative deficit in the balance of payments. Of importance was the belief that monies in circulation in West and East Africa - the'localised currency' of British silver coins - would never be redeemed in sterling and therefore didnotrequirereservebacking withgold. ${ }^{27}$

The First World War delayed the formation of an equivalent board in the East African region. The British government was already collecting substantial customs revenues at the seaports within the Sultan of Zanzibar's dominions. ${ }^{28}$ At the end of 1893, the British govern- ment took over East African territories from theImperial BritishEast AfricaCompany(IBEAC), a private company given the right through a royal charter to exploit the British sphere of influence between Zanzibar and Uganda. Between 1888 and 1890, IBEAC had issued Mombasa Coins minted in India and a mixture of rupees, annas, and pice. The silver rupee of British Indiahad been the standard coin of the East African territories, circulating at a par value of Is $4 \mathrm{~d}$ to the British pound sterling, or 15 rupees to the sterling. The First World War brought a rise in silver and in the value of the silver-based rupee, which almost doubled in value to $2 \mathrm{~s} 4 \mathrm{~d}$ and made exports more expensive ${ }^{29}$ The settled British producersinsisted the rupee be 'disciplined' in line with its original pre-war value by fiat. ${ }^{30}$ This revaluation of the rupee underpinned what came to be known as the 'East African Rupee crises', propelling the move to establish a currency board. The British government had already partially bought out the IBEAC and created the Protectorate over Uganda in 1894, and in 1895, the Company sold their remaining rights whereupon the East Africa Protectorate was constituted. ${ }^{31}$ Mombasa Currency Board was effectively replaced by the London-based East African Currency Board (EACB) in 1919, severing the monetary linkbetween East Africa and India and reducing the influence of the Asian communities in the region. The EACB issued and administered currency circulating in British East Africa: Tanganyika, Zanzibar and Pemba, Kenya, Uganda, and British Somaliland. The exchange value of the currency was controlled and maintained at par with sterling by the Board in London, which was represented in the Protectorate by a Currency Officer. The East African Currency Board arrangement lasted until 1966 when Kenya, Uganda, and Tanzania set up independent central banks. 
In an ongoing effort to reconsider the continent's colonial past, this section established that African elites were not'gatekeepers' of finance under the British Empire. London aimed at reducing intraempire transaction costs by having the colonised area adopt or integrate the home country's currency. ${ }^{32}$ Colonial currency circulation effectively strived to forge a unified and uniformed 'place ${ }^{33}$ out of the collection of social, political, and economic spaces across the British Africa. Control of national financial decisions and flows were effectively denied to African colonial states. ${ }^{34}$

\section{Sterling area to Washington: upholding power}

Cooper's book is a study of the period whenEuropean rule and powerover Africa began to unravel, from the 1940s onwards. This period was framed by the Great Crash of 1929 and Great Depression of the 1930s, marking a very uncertain financial inter-war period. ${ }^{35}$ The ensuing depression was the single most significant event to affect African colonies between 1929 and $1935 .{ }^{36}$ This was a period of implosion of world trade and global flows being channelled through regional and colonial arrangements such as the British Commonwealth. ${ }^{37}$ 'Conjoined' to Empire, ${ }^{38}$ colonies did not have the wherewithal to manage the global crises nationally. Ochonu argues that' ${ }^{\prime}$ mpire solidarity'to redress in British accounts was achieved on the backs of Nigerian peasants and workers ${ }^{39}$ in the form of retrenchment, suspension of public works, wage cuts, export expansion, aggressive revenue generation, and currency withdrawals. Colonial support for Britain's recovery continued into the early 1950s as part of Britain's post-war recovery. ${ }^{40}$ Britain, as with other European governments, was subject to domestic pressures vocalised through universal suffrage, social unrest, and could no longer impose the national effects of supporting a global Sterling tied to the Gold Standard. Britain lost its place at the global heights of monetary power as it departed from the gold standard in 1931, reverting to afree-floating exchangerate and was officiallyina depression.

As currency conversion to Sterling was automatic under a fixed exchange rate, when Britain left the gold standard in 1931, the colonies had to follow. In 1933, the dollar went off gold and failure of the World Economic Conference in June of that year to secure an agreed upon international monetary system underpinned the formation of Britain's Sterling Area. ${ }^{41}$ London's strategy - mapped by the Treasury, the Bank of England, the Commonwealth Office, and private financial actors - maintained financial structural power within large areas of the globe, even as the USA's new financial power grew. ${ }^{42}$ Britain's political position of global domination ensured that the Sterling continued as 'master currency' within its colonies. ${ }^{43}$ The rules of membership to this Britain's currency club were as follows: all dollars earned, and gold produced or acquired, had to be sold to the British Treasury. ${ }^{44} \mathrm{The}$ country's sterling account would be credited by the Bank of England. Exceptionally, South Africa maintained established rights to sell gold to the USA but other African members could not buy nonster- ling assets or securities without permission from the London. So, while all membercountries could theoretically draw on the pool of dollar reserves in London, they were in short supply and borrowing was discouraged. Greaves ${ }^{45}$ points out that 'sterling balances', the liabilities of Britain to overseas countries, increased to the colonies and diminished to the Dominions and other foreign countries. As sheexplains: from 1946 to 1953, liabilities tothecolonies were more thandoubled while thosetoother areas declined by over 20 per cent; the sterling assets of the colonies had risen to nearly $£ 1.3$ billion. What this means is that the wealth of the colonies was in London, reflecting 'a long historical' evolutionofeconomicrelations 
between the type of country now called"underdeveloped" and an international capital and "industrial centre'. ${ }^{46}$

The Sterling Area was the first of two major features of the post-war economy. ${ }^{47}$ The other was, of course, the rise of the US as the most powerful worldeconomy and the new driver of global financial and monetary policy. A new international financial order was established under Bretton Wood's international monetary order ${ }^{48}$ where the dollar rose to international prominence as the international reserve currency; a position Strange calls 'top currency'. ${ }^{49}$ Eichengreen ${ }^{50}$ calls this 'exorbitant privilege' in reference to French finance minister d'Es- taing's observation of freedom to pursue its domestic policy objectives and run sustained balance-of-payments deficits. Its antithesis was the African debt crisis of the 1980s, where national debts rose in a world marked by the oil price shocks of the 1970s, the expansion of the Eurodollar market - led by Britain - global stagflation, the fall of Africa's commodity prices, and a rise in real world interest rate. African countries'political economies were further affected by the dismantlement of capital controls and emergence of financial markets of mobile globalcapital. ${ }^{51}$

\section{Central bank authority: gatekeepers of growth}

While the 'Third World' received advice by US policy-makers to develop independent mon- etary institutions and policies in line with its new policy ideology of 'embedded liberalism', ${ }^{52}$ most African countries faced a malfunctioning world economy that dealt savage blows to their economies ${ }^{53}$ The newly independent states incurred increasing public expenditures in a world shaped by the resurrection of global finance which, like a phoenix risen from the ashes, ${ }^{54}$ soared to new heights of power. Financial globalisation developed as markets actors pushed for greater liberalisation and free cross-border movement of financial flows. ${ }^{55}$ These changes led to profound structural changes in the organisation of global finance as states adjusted to the new normal of financial globalisation. ${ }^{56}$ IFIs, with Washington at the helm, increasingly encroached into domains of African politics and governance ${ }^{57}$ - going beyond their original mandate - to advocate austerity policies through Structural Adjustment Programmes (SAPs). ${ }^{58}$

Globalisation of financial markets, the trading of more complex financial instruments, and the application of new communication technologies make risk management central to questions of financial governance. It is here that developing countries' central banks took on the pivotal role to navigate between national territorial economies and global markets. Politicians in developing countries were advised to increase central bank independence in order to signal increased credit worthiness to potential international investors and creditors willing to finance national debts. ${ }^{59}$ This meant implementing trade liberalisation with a view to improving countries'balance of payments, controlling foreign indebtedness, rescheduling debt and developing stricter debt management, privatising public services, and deregulating in order to underpin free market development. Most importantly, it meant liberalising national capital accounts under IMF instructions. Since the beginning of the 1980s, African countries have moved to more market-based financial systems with greater autonomy and accountability applying tocentral banks, whoincreasingly played the pivotalrole offinancial gatekeepers of growth, as expounded by Maxfield.

Forinstance, South Africa's stransformation in the early 1990s was not aradical break with the past. ${ }^{60}$ Although Johannesburg was, and still is, the leading economic and financial 
African city, the transfer of political power in 1994 followed on the collapse of the Rand in 1984 and a debt crisis in $1985 .{ }^{61}$ The African National Congress abandoned the idea of devel- oping a radical alternative macroeconomic framework ${ }^{62}$ as policy was shaped by structural adjustment policy (SAP) frameworks through an $\$ 850$ million loan. ${ }^{63}$ The South African Reserve Bank (SARB) obtained 'complete instrumental independence' under the new con- stitution. The ANC liberalised the economy as it adopted its Growth, Employment, and Redistribution (GEAR) policy in 1996. GEAR was based on a neo-classical macroeconomic model forwarded by the SARB that was, in turn, based on the Apartheid government's neo-liberal Normative Economic Model of the 1980s. So, while African states effectively gained control of a national currency, to all intents and purposes their ability to borrow for government expenditures was almost entirely curtailed by IFI austerity measures.

African countries'position in the global economy slowly begun to change at the beginning of this century. Notably, the 2008 financial crisis took place amidst historic shifts in growth patterns around the world and Africa's place within it in a post Western-centred world order. ${ }^{64}$ The financial crisis highlighted new patterns of economic growth between the West and the emerging economies, particularly evident in globalising Asia and rising China. Working with data from 700 locations around the world, Quah ${ }^{65}$ projects that the economic centre of gravity, the global 'core', will be located between India and China by 2050.The traditional 'three worlds' of the twentieth century is giving way to new geopolitical imaginings where third/underdeveloped/ backward/developing countries are now 'emerging markets'. ${ }^{66} \mathrm{~A}$ pattern of leaderless diffusion in financial geopolitics paintsaverydifferent worldfrom that of concentrated power under the Bretton Woods system. ${ }^{67}$

There is a shift of political economic power eastwards and the integration of emerging powers into global capital system. African states are pushing forward to more deeply inte- grate their national economies into global markets and financial networks. In this context, African states are increasingly turning to private capital flows to finance growth and devel- opment. Total external flows into Africa grew sixfold from $\$ 20$ billion in 1990 to over $\$ 120$ billion in $2012 .{ }^{68}$ Private capital is now the singlelargest source of external financing for the region. ${ }^{69}$ Before 1989 , there were only eight stock markets in the entire African continent; over a very short period African states developed national equity markets, with 11 operating stock exchanges by the end of the $1990 \mathrm{~s} .{ }^{70}$ This points to contemporary growth of financial markets and clustering of services within the African context. There is a growth of interna- tional financial centres outside of developed economies, notably in Asia, the Middle East, and now in leading African countries. The following section draws on Lagos as an excellent example of a powerful emerging African gateway. Lagos State is positioning the megacity as strategic site connecting global flows to West Africa.

\section{Lagos: rise of an African financial 'gateway'}

As the world continues to acknowledge Lagos as a regional financial hub, we as government have demonstrated the commitment to strengthen this position through deliberate policies aimed at improving the business climate in our state. ${ }^{11}$

The government of the state of Lagos - Nigeria's former capital - is building a new city, Eko Atlantic, which is set to become the new financial centre of Nigeria and West Africa. The Lagos State and State Governor's office are positioning the megacity as gateway to West Africa under the rubric of 'Lagos Global'. In this rapidly urbanising world of increased 
municipal and city power, Lagos is not simply mirroring existing global financial geography but rather offers an interesting case study of how a subnational government, Lagos State, is directing global flows through a growing African megacity. This reflects Germain's ${ }^{72}$ point that states reach out and embed financial markets within their jurisdiction. Yet, while Germain, and most international political economic (IPE) scholars, focus on the nation-state as the site of leading public authority financial action, Lagos highlights subnational govern- ance as spearing forward a location's key role and geographical advantagesininternational/ global distribution networks.

The term 'gateway' is progressively used around the world in policy and academia to speak of, advocate, and study the international dimensions of configurations of political economic power in specific strategic locations. This reveals public authorities' intentions to profit from transnational flows by directing goods, services, capital flows, peoples, and ideas ${ }^{73}$ via hubs that can ensure global connectivity and smoothly embedded transition of exchanges. As investment in Africa increases, actors are identifying key countries to serve as points of entry, gateways, into the continent, as well as act as their headquarters. Place/ location for financial centres, even in a world of digital fluidity, remains fundamental to the organisation of global finance. The need for these'springboard' countries is underscored by the fact that foreign investment into Africa is no longer concentrated in isolated countries but spreading throughout the continent. However, if we use the concept 'international financialcentre(IFC)' to study what is taking place across the African continent we (a) will not see any centres worthy of name beyond the well-recognised centre of Johannesburg, (b) will effectively see an incomplete image of Africa's evolving financial architecture as early finan- cial centre formation is not 'captured' in analysis, and, (c) will miss the bigger picture of the continent's growing financial geopolitics. In an endeavour to understand how financial gate- keeping power is gradually transferring back to Africa, I therefore suggest the employment of the 'gateway' concept.

There is a promising body of literature on the development of financial centres in Asian hubs, ${ }^{74}$ as well other emerging areas such as the Middle East, ${ }^{75}$ along with new literature on African gateways ${ }^{76}$ that can inform our analysis of Africa's new financial gateways. From an African perspective, financial centre strategies serve to internationalise specific locations as multi-modal nodes between the national and the global political economy as finance's digital and fluid qualities in a globalised world are tethered to and dependent on these strategic nodes. The logistical importance of physical locations serving as gateways for communica- tion, transportation, and distribution nodes increases our understanding of economic, tech- nical, political, and financial world integration. Gateways mediate between global conditions and national (or subnational and local) interests, whether these are for geopolitical reasons, ${ }^{77}$ or for stimulating local economic development strategies. ${ }^{78}$ Gateway strategies serve to internationalise specific locations as multi-modal nodes which possess the potentiality of controlling the flows of good and people. ${ }^{79}$ Much of this literature stems from geography ${ }^{80}$ as the field identifies cities and urban spaces ${ }^{81}$ as connection nodes to international markets and networks. Economic geography can be traced to von Thünen's concentric ring models, employed by scholars such as Braudel ${ }^{82}$ to think about the spatiality of cities in world econ- omies, global trading routes, and capital networks. Regional studies ${ }^{83}$ argue that gateways act as saddle points between regions and the global economy. These gateway locations are, therefore, involved in the deterritorialisation and reterritorialisation of various components of the globaleconomy, notably supply chains, investmentandfinancialmarkets,information 
and communication technologies, as well as labour migration. ${ }^{84}$ Deterritorialisation and reterritorialisation refer to the re-configuration and re-scaling of forms of territorial organi- sation such as cities and states within globalisation processes. ${ }^{85}$

\section{MakingLagos Africa'smodelmega-cityandglobaleconomicandfinancialhub ${ }^{86}$}

Applying gateway concept to analyse megacities such as Lagos allows an embedded and transscalar understanding of globalised processes and the ways in which they anchor to specific locations. Lagos is an astonishing case of urban obscurity to megacity power in the space of three decades. Lagos in the 1990s was a city where the state was absent. ${ }^{87}$ The city was largely outside of global production and distribution networks. The federal government had withdrawn to Abuja in 1991, and the city was left to its own devices. The state that'came back in' to govern Lagos was not the Nigerian federal state but Lagos State Government. The Office of the Governor had been created in 1967, along with the creation of Lagos State. The 1999 constitution gave states wide powers to manage issues of local government organ- isation and structure. It is this devolvement that will permit Lagos State to steer the fast growing city into West Africa's hub, while the federal government plays a more supportive secondary role. This constitutional provision has historically led to prolonged disputes between the federal government and Lagos State government. The 2015 presidential vote, however, was the first democratic transfer of power in 16 years which saw Muhammadu Buhari elected President. Buhari was the presidential candidate of the All Progressive Congress (APC) formed in 2013. Now, Lagos State and the Federal Government are run by the same party, the APC. This facilitates Lagos State's ambitions to place the mega-city as regional financial and economic hub.

Lagos already has a financial centre including Nigeria's Central Bank (NCB) and Nigeria Stock Exchange (NSE). The main elements of government financial management systems are present in Lagos State, which include budgeting, internal control, accounting, Treasury management, Central Bank of Nigeria $(\mathrm{CBN})$, financial reporting, and auditing arrangements. Along with the CBN, the treasury, State Government has developed and implemented pro- cedures to improve the effectiveness of tax revenue collection and monitoring. Lagos's financial centre is also being enhanced through the Economic Community of West African States' (ECOWAS) and West African Capital Markets Integration (WACMIC) project. African regional economic communities (RECs) have long aimed to promote regional financial inte- gration, including future monetary unions, in the continent's sub-regions. WACMIC, estab- lished in 2013, is a governing body for the integration of West African Capital Markets. With Nigeria at the helm, the platform integrates the Nigerian Stock Exchange (NSE) with the Ghana Stock Exchange (GSE) and Cote d'Ivoire Bourse Régionale des Valeurs Mobilières (BRVM). WACMIC effectively creates a West African investment 'cloud' steered by Nigerian financial institutions. This financial gateway facilitates regional cross-border listing and trad- ing, permitting companies and investors in Nigeria to raise money for trade in stocks and bonds listed in Ghana or Côte d'Ivoire. The governing body includes stakeholders such as the West African Monetary Institute (WAMI) and the West African Economic and Monetary Union (WAEMU), composed primarily of former French colonies.

The smallest of Nigeria's 36 states, Lagos mega-city and Lagos State are essentially becom- ing one and the same thing. The megacity of an estimated 21 million peoplehas overtaken Cairo as Africa's largestmetropolisandhasanestimatedGrossDomesticProductof $\$ 136$ 
billion. ${ }^{88}$ Being ranked as Africa's largest economy is seen by Nigerian financial sector, based on Victoria Island, as an opportunity to brand itself as the gateway to African markets for its global investors. ${ }^{89}$ Governor Abode aims to expand capital expenditure in Lagos 'such that in another two to three years, Lagos State will become the third largest economy in Africa' ${ }^{90}$ The development of Eko Atlantic, built inside the Great Wall of Lagos which creates new urban space claimed from the sea, is expected to underpin the metropolis' role as financial epicentre of West Africa. Along with Eko Atlantic, Lagos State attracted \$1.65 billion for the Lekki Deep Seaport and \$12 billion for Dangote's Refinery and Petrochemical Plant. ${ }^{91}$ Along these lines, Governor Ambode launched an international investment one-stop shop, Lagos Global, in 2016 in the Office of Overseas Affairs and Investment. A one-stop investment centre had also been set up in Abuja in $2006,{ }^{92}$ with the aim of setting up operations for investment in Lagos' financial district. However, Lagos State moved independently to facil- itate investment through the State Governor's Office as the city became identified as one of three 'command centres' for the African economy, along with Johannesburg and Nairobi. ${ }^{93}$ Lagos has effectively been confirmed as one of four cornerstones of the African Development Bank (AfDB), the African Securities Exchanges Association (ASEA), and African Exchanges Linkage Project (AELP). ALEP will link Nairobi Securities Exchange (NSE), Casablanca Stock Exchange (CSE), the Johannesburg Stock Exchange (JSE), and the Nigerian Stock Exchange (NiSE) in line with AfDB and ASEA's goal to deepen Africa's financial markets.

Lagos State does not have control of monetary policy, but Nigeria's Vision 20:2020 (NV20:2020) is an enabling federal policy that identifies the financial sector at the heart of achieving the countries development goals through deepened financial markets, enhanced intermediation processes, and increased connectivity with external financial markets. To this end, Nigerian banks have undergone important reforms, in 2004, under the supervision of the Central Bank of Nigeria. A second policy goal in line with the NV20:2020 is a 'cashless' economy. The aim is to improve the effectiveness of monetary policy and underpin economic growth through digital payments system. Nigeria has only 44 per cent penetration of digital payments - less than 1 per cent of total transactions. ${ }^{94} \mathrm{NCB}$ placed restrictions on cash withdrawals and put in place anew nationale-IDcard that will act as a payments smart card. The National Identity Management Commission (NIMC) has issued a MasterCard-branded identity card with electronic payments functionality that will merge biometric data from all government agencies onto this one card. 'Cash-less Nigeria' is Africa's broadest financial inclusion programme.

Thissectionestablishesthatasthecontinent'slargestmegacity,Lagos, isattheepicentre of economic activity as the State Governor's Office establishes a gateway status for West Africa. With its adjoining conurbation, Lagos is the largest city in Nigeria on the African continent. Gateway formation is being underpinned through initiatives such as 'Lagos Global', the development of Eko Atlantic, and financial investment cloud for West Africa's stock exchanges. Gateways are about the geography of politics and the politics of geography. ${ }^{95}$ Place matters ${ }^{96}$ as competition arises between African states to be leading sub-regional business and financial hubs with the ability to integratesubsidiary marketsintotheirorbit. ${ }^{97}$

\section{Conclusion}

The main premise of this paper is that, until recently, African elites did not regulate or control financial flowsmoving across thecontinent. This papermadethecaseforanewengagement 
with existing notions of 'gatekeepers' by re-examining Africa's colonial political economic history through the lens of financial. Neglecting to distinguish between types of flows has distorted our assessment of African political economic power under colonialism. Two argu- ments were made in support of this claim. Firstly, I have demonstrated that financial power was not located at a'peripheral'African gate, but resolutely held onto within leading financial centres; circumventing gatekeeping tacticsby African elites. Finance'sstructural powerwas never assigned to the colonies but managed in London through its network of key institu- tions such as the City, the Treasury, and Commonwealth Office. Bringing financial flows into the analysis, consequently, radically changes who weidentify as gatekeeper. Financial gate- keeping from the West continued as African countries became independent, authorised through Bretton Woods'IFI austerity measures. It is only in the post2000 period, in a chang- ing world order with the rise of the Asia and emerging powers, that we see powerful African states driving the integration of Africa's sub-regions into the global financial system to become what can be recognised as aspiring financial 'gatekeepers.'The second argument is that contemporary African financial control of financial flows effectively corresponds more to 'gateway' strategies than to Cooper's concept of gatekeeper used to describe a reality of the midTwentieth Century. Drawing on the case of Lagos, I demonstrate how this'gateway' concept better captures trans-scalar processes of new financial clustering in Africa's emerging markets than a concept associated with 'gates' under Empire. As financial gatekeeping was seldom an African reality, I therefore argue for use of the 'gateway' concept. The notion of gateway better captures state and inter-state restructuring under contemporary global political and economic processes.

\section{Disclosure statement}

No potential conflict of interest was reported by the author.

\section{Notes on contributor}

Elizabeth Cobbett is lecturer in the School of Politics, Philosophy, Language, and Communication Studies at the University of East Anglia. Her current research project, Growth of African Financial Networks, centres on the political economy of financial flows and emergent financial systems in Africa. Focus is on five countries South Africa, Kenya, Mauritius, Nigeria, and Morocco - for their leading role in shaping Africa's continental financial architecture. A second component investigates the development of financial technologies as Africa experiences growth of innovation and convergence between finance and technology, known as FinTech. Elizabeth was recipient of the ISA Robert and Jesse Cox Graduate Essay Award, a Social Science and Humanities Research Council of Canada's CGS Doctoral Scholarship, the Senior Women Academic Administrators of Canada: Graduate Student Award of Merit, as well as being the winner of the Foreign Affairs and International Trade Canada essay competition: Canada's Experience with NAFTA. She is currently working on a forthcoming monograph with Edward Elgar: The Political Economy of African Financial Centres: The New Realm of Global Finance'.Twitter: @CobbettEli|Website: https://eastanglia.academia.edu/ElizabethCobbett

\section{Notes}

1. Cooper, Africa Since 1940.

2. Ingham, CapitalismDivided?

3. Cooper,“Africa Since 1940,”161. 
4. Cain and Hopkins, "Gentlemanly Capitalism".

5. Ibid.

6. Strange, States and Markets.

7. Strange, "Finance, Information andPower". 8.

Ibid, 508.

9. Ibid, 510.

10. Eichengreen, Globalizing Capital.

11. Greaves, "The Colonial Sterling Balances".

12. Gardner,"The Rise and Fall of Sterling in Liberia,"2.

13. Terreblanche, A History of Inequality.

14. Houghton, "Economic Development".

15. Ibid, 11 .

16. Ally, Gold and Empire, 35.

17. Thompson, "Compromise of the Union".

18. Ibid, 76 .

19. Helleiner, "Southern Side of Embedded Liberalism".

20. Ally, Gold and Empire, 84.

21. Rooth,"Britain, South African Gold, and the Sterling Area".

22. Narsey, BritishImperialism.

23. Williamson, "What Role for Currency Boards?"

24. Narsey, BritishImperialism.

25. Cohen, "Seigniorage Gain," 494.

26. Ibid, 496.

27. Treadgold, "Colonial Currency Boards".

28. Ibid, 234.

29. Maxon,"Kenya Currency Crisis," 324.

30. Mwangi,"OfCoins and Conquest," 764.

31. Eliot, "East African Protectorate".

32. Helleiner, "Monetary Dimensions".

33. Mwangi, "OfCoins and Conquest," 766.

34. This paper recognises the very different colonial financial legacies within Africa, for instance, Great Britain's sterling zone, Portugal's escudo zone, and France's franc zone. The CFA franc zone continues as the West African CFA franc and the Central African CFA franc, two currencies that, even though separate, are in practice interchangeable, guaranteed by the French treasury and pegged to the euro. Countries within these two zones still do not have effective financial and monetarysovereignty.

35. Eichengreen, "Monetary Dimensions".

36. Anderson, "Depression, Dust Bowl, Demography".

37. Eichengreen and Irwin, "Trade Blocs, Currency Blocs".

38. Ochonu, "Conjoined to Empire".

39. Ibid, 119.

40. Krozewski, "Money and the End of Empire".

41. Kindleberger, Financial Historyof Western Europe.

42. Krozewski, "Money and the End of Empire"; and Gaitskell, "Sterling Area".

43. Strange, "Sterling and British Policy".

44. Cole and Shanks, "Policy for the Sterling Area".

45. Greaves, "The Colonial Sterling Balances,"1.

46. Ibid, 2 .

47. Copland,"Problems of the Sterling Area".

48. Ruggie, "International Regimes, Transactions, and Change".

49. Strange, "Sterling and British Policy".

50. Eichengreen.

51. Helleiner, "States and the Reemergence of Global Finance".

52. Helleiner, "Southern Side of Embedded Liberalism". 
53. Helleiner, "Africa and the International Monetary Fund".

54. Cohen,"Phoenix Risen".

55. Helleiner,"The Politics of Global Finance".

56. Germain,"Financial Governance in Historical Perspective".

57. Campbell, "Governance, Institutional Reform".

58. Cobbett, "The South African Reserve Bank".

59. Maxfield, "Gatekeepers of Growth".

60. Lester et al. "South Africa's Current Transition,"145.

61. Gelb, "South Africa's Economic Crisis".

62. Padayachee and Sherbut, "Ideas and Power,"30.

63. Bond,"Fighting Neo-liberalism,"14.

64. Gray and Murphy,"Introduction".

65. Quah, "The Global Economy's Shifting Centre".

66. Sidaway and Pryke, "Strange Geographies".

67. Cohen, "International Monetary System,"455; italics in original.

68. Ibid, 13 .

69. Sy, "Private Capital Flows".

70. Kenny and Moss, "Stock Markets in Africa".

71. Office of Overseas Affairs and Investment, "Welcome to Lagos State".

72. Germain, "Financial Governance in Historical Perspective".

73. Evans, "The AsiaPacific Gateway"; and Montsion, "SofteningCanada's Gateway".

74. Gipouloux, GatewaystoGlobalisation; and Youngetal.Competitionamong FinancialCentres.

75. Zhao and Karagoz, "Potential of Istanbul".

76. Cobbett, "Johannesburg".

77. Comtois and Wang, "Géopolitique et transport".

78. Woo, "Building the Asia Pacific".

79. Burghardt, "Hypothesis about Gateway Cities".

80. Burghardt, "A Hypothesis about Gateway Cities"; Bird, "Gateways"; and Pain, "New Worlds' for 'Old"”.

81. Ley and Titchener, "Immigration, Globalisation".

82. Braudel, Perspective of the World.

83. Andersson and Andersson,"Gateways to the Global Economy"; and Taylor,"World City Network".

84. Tuathail and Luke, "Present at the (Dis)integration".

85. Brenner, New State Spaces.

86. Office of Lagos State, "State Vision".

87. Michael,"Lagos Shows How a City can Recover".

88. Ikwuamaeze, "Lagos GDP".

89. Matutu,"The Nigerian Stock Exchange".

90. Ambode, "My Random Thoughts".

91. Vanguard,"Nigeria".

92. OECD, "Investment Policy Reviews,"284.

93. Office of Overseas Affairs and Investment, "Welcome to Lagos State".

94. Kendall et al.,"Sub-Saharan Africa,"53.

95. Smith, "Uneven Development".

96. Lavelle,"Architecture of Equity Markets".

97. Sy, "Financial Integration".

\section{Bibliography}

Ally, Russell. Gold and Empire: The Bank of England and South Africa's Gold Producers, 1886-1926. Johannesburg: Witwatersrand University Press, 1994.

Ambode, Akinunmi."My Random Thoughts: On Lagos, and Accelerating Development across Nigeria." August 28, 2017. http://akinwunmiambode.com/my-random-thoughts-on-lagos-and-accelerating- developmentacross-nigeria/ 
Andersson, Ake E., and David E. Andersson, eds, Gateways to the Global Economy. Northampton, MA: Edward Elgar Publishing, 2000.

Anderson, David. "Depression, Dust Bowl, Demography, and Drought: The Colonial State and Soil Conservation in East Africa during the 1930s." African Affairs 83, no. 332 (1984): 321-344 http:// www.jstor.org/stable/722351.

Bird, James. "Gateways: Slow Recognition but Irresistible Rise." Tijdschrift Voor Economische En Sociale Geografie 74, no. 3(1983): 196-202.

Bond, Patrick."Fighting Neo-Liberalism: The South African Front." South African Report 12, no. 2 (1997): 14 http://www.africafiles.org/article.asp?ID=3851.

Braudel, Fernand. The Perspective of the World. Vol. 3 of Civilization and Capitalism, 15th-18th Century. Translated by Siân Reynolds. New York: Harper \& Row, 1984.

Brenner, Neil. New State Spaces: Urban Governance and the Rescaling of Statehood. Oxford: Oxford University Press, 2004.

Burghardt, Andrew F. "A Hypothesis about Gateway Cities." Annals of the Association of American Geographers 61 (1971): 269-285

Cain, P.J., and A. G. Hopkins. "Gentlemanly Capitalism and British Expansion Overseas I. the Old Colonial System, 1688-1850."The Economic HistoryReview 39, no.4(1986):501-525.

Campbell, Bonnie."Governance, Institutional Reform \& the State: International Financial Institutions \& Political Transition in Africa." Review of African Political Economy, Vol. 28, no. 88, Africa's Future: That Sinking Feeling (2001):155-176.http://www.jstor.org/stable/4006714

Cassis, Youssef. Capitals of Capital: The Rise and Fall of International Financial Centres 1780-2009. Cambridge: Cambridge University Press, 2006.

Cobbett, Elizabeth. "The South African Reserve Bank and the Telling of Monetary Stories." Nokoko 1 (2010): 67-98.

Cobbett, Elizabeth."Johannesburg: Financial 'Gateway' to Africa."In The Power of Cities in International Relations, edited by Simon Curtis, 151-164. Oxon: Routledge, 2014.

Cohen, Benjamin J. "Phoenix Risen: The Resurrection of Global Finance.” World Politics 48, no. 2 (1996): 268-296 http://www.jstor.org/stable/25053963.

Cohen, Benjamin J.“The International Monetary System: Diffusion and Ambiguity.”International Affairs. 84, no. 3 (2008): 455-470.

Cohen, Benjamin J.“The Seigniorage Gain of an International Currency: AnEmpirical Test.”The Quarterly Journal of Economics 85,no.3(1971),494.http://www.jstor.org/stable/1885935

Comtois, Claude, and James Wang. "Géopolitique Et Transport: Nouvelles Perspectives Stratégiques Dans Le Détroit De Taïwan.”Études Internationales 34, no. 2(2003): 213-227.

Cooper, Frederick. Africa since 1940. New York: Cambridge University Press, 2002.

Copeland, Douglas. "Problems of the Sterling Area: With Special Reference to Australia."Essays in International Finance No.17, September 1953. https://www.princeton.edu/ ies/IES_Essays/E17.pdf Eichengreen,

Barry.ExorbitantPrivilege:TheRiseandFalloftheDollarandtheFutureoftheInternational Monetary System. Oxford: Oxford University Press, 2011.

Eichengreen, Barry. Globalizing Capital: A History of the International Monetary System. Princeton, NJ: Princeton University Press, 1996.

Eichengreen, Barry, and Douglas A. Irwin.“"Trade Blocs, Currency Blocs and the Reorientation of World Trade in the 1930s." Journal of International Economics 38 (1995): 1-24. http://search.ebscohost. com/login.aspx ?direct=true $\&$ db=bth $\& A N=9504102819 \&$ authtype $=$ sso $\&$ custid $=$ s $8993828 \&$ site $=e \quad$ dslive\&scope $=$ site

Eliot, Charles. The East African Protectorate. London: Edward Arnold, 1905. https://archive.org/details/ eastafricaprotec00eliouoft.

Evans, Paul. "The Asia Pacific Gateway and the Reconfiguration of North America." Canadian Political Science Review 2, no. 4 (2008): 93-98.

Fashola, Babatunde."Governor Babatunde Fashola, Lagos State, Nigeria."International Bar Association Conference, Boston, 2013. http://www.ibanet.org/Conferences/Fashola.aspx.

Gaitskell, Hugh. "The Sterling Area." International Affairs 28, no. 2 (April 1952): 170-176. http://www. jstor.org/stable/2604014 
Gardner,L.A.“TheRiseandFallofSterlinginLiberia,1847-1943.”TheEconomicHistoryReview67,no. 4(2014): 1089-1112. doi:10.1111/1468-0289.12042.

Gelb, Stephen, ed. South Africa's Economic Crisis. CapeTown:DPhilip; Atlantic Highlands, NJ:Zed Books, 1991.

Germain, Randall D. "Financial Governance in Historical Perspective: Lessons from the 1920s." Paper presented at the Annual Conference of the 2008 Canadian Political Science Association, University of British Columbia.https://cpsa-acsp.ca/papers-2008/Germain.pdf.

François, Gipouloux. Gateways to Globalisation: Asia's International Trading and Finance Centres. Cheltenham: Edward Elgar, 2011.

Gray, Kevin, and Craig N. Murphy."Introduction: Rising Powers and the Future of Global Governance."

Third World Quarterly 34, no. 2 (2013): 183-193. doi:10.1080/01436597.2013.775778.

Greaves, Ida. "The Colonial Sterling Balances." Essaysin International Finance, No. 20. Princeton, NJ: Princeton University Press, 1951. 10.2307/2226970

Harvey, Cole, and Michael Shanks. Policy for the Sterling Area. London: Fabian Publications, 1953.. https:// digital.library.lse.ac.uk/objects/lse:lim248wuc.

Helleiner, Eric. States and the Reemergence of Global Finance: From Bretton Woods to the 1990s. Ithaca, NY: Cornell University Press, 1994.

Helleiner, Eric. "The Politics of Global Finance: Does Money Make the World Go 'Round?" The Trudeau Foundation, the Trudeau Foundation Papers 1 (2008): 51-76 http://www.trudeaufoundation.ca/sites/ default/files/u5/pages_de_trudeaupapers2009_-_text_from_eric_helleiner.pdf.

Helleiner, Eric. "The Southern Side of Embedded Liberalism: The Politics of Postwar Monetary Policy in the Third World." In Monetary Orders: The Political Foundations of 21st Century Money, edited by J. Kirshner. Ithaca: Cornell University Press, 2003.

Helleiner, Eric. "The Monetary Dimensions of Colonialism: Why Did Imperial Powers Create Currency Blocks?" Geopolitics 7, no. 1 (2002): 5 http://search.ebscohost.com/login. asp ?direct=true $\& \mathrm{db}=\mathrm{a} 9 \mathrm{~h} \& \mathrm{AN}=7353229 \&$ site $=$ eds-live $\&$ scope $=$ site .

Helleiner, Gerald K. Africa and the International Monetary Fund: Papers Presented at a Symposium Held in Nairobi, Kenya,May13-15,1985.n.p.Washington,DC:InternationalMonetary Fund, 1986.

Houghton, Hobart D. "Economic Development." In The Oxford History of South Africa, Vol. П. edited by Monica Wilson and Leonard Thompson, 1-48. Oxford: Oxford University Press, 1971.

Ikwuamaeze, Vivian. "Lagos GDP Hits \$136 Billion.", 2017. http://www.nigeriacommunicationsweek. com.ng/news/lagos-gdp-hits-136bn

Ingham, Geoffrey K. Capitalism Divided?: the City and Industry in British Social Development. n.p. Basingstoke: Macmillan, 1984.

Kendall, Jake, Robert Schiff, and Emmanuel Smadja. "Sub-Saharan Africa: A Major Potential Revenue Opportunity for Digital Payments."McKinsey, 2016. http://www.mckinsey.com/industries/financialservices/our-insights/sub-saharan-africa-a-major-potential-revenue-opportunity-for-digital- payments.

Kenny, Charles J., and Todd J. Moss. “Stock Markets in Africa: Emerging Lions or White Elephants?”World Development 26, no. 5 (1998): 829-843 http://www.sciencedirect.com/science/journal/0305750X.

Kindleberger, Charles P. A Financial History of Western Europe. Oxon: Routledge, 1984.

Krozewski, Gerold. Money and the End of Empire: British International Economic Policy and the Colonies, 1947-58. Basingstoke: Palgrave Macmillan, 2001.

Lavelle, Kathryn C. "Architecture of Equity Markets: The Abidjan Regional Bourse." International Organization 55, no. 3 (2001): 717-742 http://www.jstor.org/stable/3078662.

Lester, Alan, Etienne Nel, and Tony Binns. "South Africa's Current Transition in Temporal and Spatial Context." Antipode 32, no. 2 (2000): 135-151 http://search.ebscohost.com/login. asp $x$ ?direct $=$ true $\& \mathrm{db}=\mathrm{a} 9 \mathrm{~h} \& \mathrm{AN}=3364903 \&$ site $=$ eds-live $\&$ scope $=$ site.

Ley, David, and Judith Tutchener. "Immigration, Globalisation and House Prices in Canada's Gateway Cities." Housing Studies 16, no. 2 (March 2001): 199-223.

Matutu, Thando. The Nigerian Stock Exchange: A Gateway to African Markets. CNBC Africa. http://www. cnbcafrica.com/insights/special-reports/world-economic-forum/the-nigerian-stock-exchange-a- gateway-toafrican-markets/. 
Maxfield, Sylvia. Gatekeepers of Growth: The International Political Economy of Central Banking in Developing Countries. Princeton, NJ: Princeton University Press, 1997.

Maxon, Robert."The Kenya Currency Crisis, 1919-21 and the Imperial Dilemma."The Journal of Imperial and CommonwealthHistory 17,no.3(1989):324-348.doi:10.1080/03086538908582796.

Michael,Chris. 2016. "Lagos Shows How a City Can Recover from a Deep, Deep Pit':Rem Koolhaas Talks to Kunlé Adeyemi." The Guardian, February 27. https://www.theguardian.com/cities/2016/feb/26/ lagos-rem-koolhaaskunle-adeyemi.

Montsion, Jean Michel. "Softening Canada's Gateway to the Asia Pacific? Community Perspectives on Vancouver's International Visage.”Canadian JournalofUrbanResearch20,no.2(2011):36-55. Mwangi,

Wambui. 2001."OfCoins and Conquest: The East African Currency Board, the Rupee Crisis, andtheProblemofColonialismintheEastAfricanProtectorate."ComparativeStudiesinSocietyand History 43, no.4(2001): 763-787.http://www.jstor.org/stable/2696669.

Narsey, Wadan. British Imperialism and the Making of Colonial Currency Systems. Palgrave Studies in the History of Finance. Basingstoke: Palgrave Macmillan, 2016.

Ochonu, Moses. "Conjoined to Empire: The Great Depression and Nigeria." African Economic History 34 (2006): 103-145.doi:10.2307/25427028.

OECD. Investment Policy Reviews: Nigeria 2015. Paris: OECD Publishing, 2015. http://www.oecd.org/ countries/nigeria/oecd-investment-policy-reviews-nigeria-2015-9789264208407-en.htm.

Office of Lagos State. "State Vision.” July 25, 2017. http://governor.lagosstate.gov.ng/.

Office of Overseas Affairs and Investment. "Welcome to Lagos State." http://www.lagosglobal.org/ aboutlagos-state/.

Padayachee, Vishnu, \& Graham Sherbut. "Ideas and Power: Academic Economists and the Making of Economic Policy. The South African Experience in Comparative Perspective."Working paper No. 43. Population Studies and Development Studies, University of KwaZulu-Natal, Durban, 2007. https:// etudesafricaines.revues.org/16811.

Pain, Kathy. "New Worlds' for 'Old'? Twenty-first-Century Gateways and Corridors: Reflections on a European Spatial Perspective.” International Journal of Urban \& Regional Research 35, no. 6 (2011): 1154 1174.

Quah, Danny. “The Global Economy's Shifting Centre of Gravity.” Global Policy 2, no. 1 (2011): 3-9 http://search.ebscohost.com/login.aspx?direct=true $\& \mathrm{db}=$ edswss $\& A N=000208582800002 \&$ site $=e \quad$ dslive\&scope $=$ site.

Reserve Bank of South Africa. "Mandate." n.p. https://www.resbank.co.za/AboutUs/Mandate/Pages/ MandateHome.aspx

Rooth, Tim. "Britain, South African Gold, and the Sterling Area, 1945-50." The Journal of Imperial and Commonwealth History 32, no. 1 (2004): 93-114 http://search.ebscohost.com/login. aspx?direct=true $\& \mathrm{db}=\mathrm{a} 9 \mathrm{~h} \& \mathrm{AN}=13639387 \&$ site=eds-live $\&$ scope $=$ site.

Ruggie, John G."International Regimes, Transactions, and Change: Embedded Liberalism in the Postwar Economic Order."International Organization 36, no. 2, (1982): 379-415. http://search.ebscohost.com/ login.aspx?direct=true $\& \mathrm{db}=$ edsglt $\& A N=$ edsgcl.2253269\&site=eds-live \&scope=site.

Sidaway, James Derrick, and Michael Pryke. "The Strange Geographies of 'Emerging Markets." Transactions of the Institute of British Geographers, 25, no. 2 (2000): 187-201. http://www.jstor.org/ stable/623191

Smith, Neil. Uneven Development: Nature, Capital, and the Production of Space. Athens: University of Georgia Press Strange, 2008.

Strange, Susan."Finance, Information and Power." Review of International Studies 16, no. 3 (1990): 259- 274 http://www.jstor.org/stable/20097226.

Strange, Susan. States and Markets. London: Pinter Publishers, 1988.

Strange, Susan."Sterling and British Policy: A Political View.”International Affairs 47, no. 2 (1971): 302-315 http://www.jstor.org/stable/2613930.

Sy, Amadou N.R."Financial Integration in the West African Economic and Monetary Union."IMF Working Paper Monetary and Financial Systems Department, WP/06/214, 2006. https://www.imf.org/en/ Publications/WP/Issues/2016/12/31/Financial-Integration-in-the-West-African-Economic-and- MonetaryUnion-19815 
Sy, Amadou N. R. "Private Capital Flows, Official Development Assistance, and Remittances to Africa: Who Gets What?" Brookings. https://www.brookings.edu/research/private-capital-flows-official- developmentassistance-and-remittances-to-africa-who-gets-what/

Peter, Taylor. World City Network: A Global Urban Analysis. London: Routledge, 2004.

Terreblanche, Sampie. A History of Inequality in South Africa 1652-2002. 3rd ed. Pietermaritzburg: University of Natal Press, 2005.

Thompson, Leonard.“The Compromise of the Union.”In The Oxford History of South Africa, Vol. П edited by MonicaWilson andLeonardThompson, 343-349.Oxford:Oxford UniversityPress, 1971.

Tuathail, Gearoid O, and Timothy W Luke. "Present at the (Dis)Integration: Deterritorialization and Reterritorialization in the New Wor(L)D Order."Annals of the Association of American Geographers, 84, no. 3 (1994): 381-398.

Treadgold, Malcolm. “Colonial Currency Boards: The Seigniorage Issue."History of Economics Review 41, no. 1, (2005).http://www.hetsa.org.au/historyeconreview/journalpresent.html

Vanguard. "Nigeria: Ambode Launches One-Stop Shop for Investors." AllAfrica. http://allafrica.com/ stories/201604050321.html

Williamson, John. "What Role for Currency Boards?" Policy Analyses in International Economics. Ottawa: Peterson Institute for International Economics, 1995.

Woo, Yuen Pau. Building the Asia Pacific Gateway Economy Canada-Asia Viewpoints. Vancouver: Asia Pacific Foundation of Canada, 2007.

Young, Soogil, Dosoung Choi, Jesus Seade, and Sayuri Shirai, eds. Competition among Financial Centres in AsiaPacific:Prospects, Benefits, Risks and Policy Challenges. Singapore: Institute of Southeast Asian Studies, 2009.

Zhao, Xin, and Murat Karagoz."Potential of Istanbul as an International Financial Center: A Comparison with Shanghai and Dubai." Procedia Economics and Finance 38, The 5th Istanbul Conference of Economics and Finance (2016): 232-244. 